\title{
HUBUNGAN TINGKAT RELIGIUSITAS DENGAN SIKAP KONSUMTIF PADA IBU RUMAH TANGGA
}

\author{
Rina Ekaningdyah Anggarasari \\ Universitas Gadjah Mada
}

\begin{abstract}
INTISARI
Penelitian ini bertujuan untuk mengetahui hubungan tingkat religiusitas dengan sikap konsumtif pada ibu rumah tangga. Hipotesis yang diajukan adalah ada hubungan yang negatif antara tingkat roligiusitas dengan sikap konsumtif pada ibu rumah tangga. Semakin tinggi tingkat raligiusitas akan semakin rendah sikap konsumtifnya, begiu juga sebaliknya semakin rendah tingkat religiusitas semakin tinggi sikap konsumtif. Subjek penelitian adalah ibu-ibu rumah tangga di Perumahan Purwosari. Perumahan Karang Asri, dan wilayah RT C2 RW I Kelurahan Kranji, Purwokerto Me tode pengumpulan data dilakukan dengan menggunakan angket tingkat religiusitas dan angket sikap konsumbif. Analisis data yang digunakan untuk menguji hipotesis adalah teknik korelasi product moment dari Pearson. Hasil analisis menunjukkan $r_{n y}=0,330(P<0.07), r^{2}=0,109$ yang berarti ada hubungan negatif yang sangat signifikan antara tingkat religiusitas dengan sikap konsumtif pada ibu rumah tangga, dengan sumbangan tingkat religiusitas terhadap sikap konsumtif sebesar $10,9 \%$.
\end{abstract}

Kata kunci: tingkat religiusitas, sikap konsumtif, ibu rumah tangga

Rina Ekaningdyah Anggarasari adalah alumnus Fakultas Psikologi UGM Yogya karta. Meminati kajian Psikologi Konsumen.

\section{PENGANTAR}

Cepaknya arus informasi telah memungkinkan apa yang terjadi di belahan dunia sału segera dikełahui dan mempengaruhi tindakan dan keputusan orang-orang dalam berbagai bidang di belahan dunia lain. Kemajuan di berbagai bidang telah membawa implikasi pada sikap dan perilaku membeli seseorang. Membanjirnya barang dan jasa di pasaran mempengaruhi sikap seseorang terhadap pembølian dan pemakaian barang. Pembelian dan pemakaian suatu produk 
bukan lagi semata-mata untuk memenuhi kebutuhan. Seringkali pembelian dan pemakaian barang itu didorong oleh keinginan yang kurang berguna seperti, mengikuti mode, menaikkan pretise, menjaga gengsi, dan berbagai alasan lain yang sifatnya kurang penting.

Secara langsung maupun tidak, berbagai kemajuan ini juga menyebabkan daya beli dan hasrat konsumtif juga bertambah. lbu rumah tangga sebagai salah satu kelompok konsumen mempunyai peran yang penting dalam proses pembelian suatu barang (Kottler, 1984). Ibu rumah tangga adalah pembeli utama bagi keluarga. Biasanya ibu rumah tangga yang memegang uang dan mengatur pengeluaran. Dapat dikatakan ibus rumah tangga merupakan agen pembelian (Swastha dan Handoko, 1987).

Keadaan inilah yang sedikit banyak mendorong seorang bu rumah tangga untuk bersikap konsumtif. Ditambah lagi dengan kepandajan para produsen dalam memasarkan produknya (Wirawan, 1991). Produsen berlomba-fomba mempromosikan produknya dengan menggunakan berbagai macam cara, yang kadang-kadang berlebihan. MenurutSigit (Sulistyowati, 1989), hal ini dapat mendorong konsumen untuk cenderung mengambil keputusan membeli yang didasarkan pada emosi semata. Hadipranata (Nashori, 1991) juga mengalakan bahwa wanita sering menggunakan emosi dalam berbelanįa.

\section{TELAAH PUSTAKA}

Sikap konsumtif adalah kecenderungan hidup dengan keinginan membeli barangbarang yang kurang atau tidak diperlukan sehingga sifatnya menjadi berlebihan. Manusia menjadi lebih mementingkan faktor keinginan (wam) darpada kebutuhan (need). dan cenderung dikuasai oleh has ral keduniawian dan kesenangan material semata.
Adanya sikap seperti ini membuat orang sefalu merasa tidak puas jika barang yang diinginkan belum dimiliki. Sikap hidup seperti ini merupakan salah satu masalah sosial yang cukup serius, sebab akan membawa dampak negatif bagi masyarakat Indonesia umumnya dan ibu rumah tangga pada khususnya.

Sikap dan perilaku seseorang untuk membeli barang atau jasa, dipengaruhi banyak faktor, salah satunya adalah agama. Menu rut Hirschman (Engel dkk., 1990), konsumen yang makin mengidentifikasikan diri dengan agama yang dianuthya, maka semakin besar kemungkinan terkena pengaruhnya. Agama meletakkan dasar pengertian dan konsep moral dalam diri seseorang. Konsep moral dari agama sangat menentukan sistem kepercayaan, sehingga seringkali ajaran moral dari agama inilah yang menjadi determinan tunggal yang menentukan sikap (Azwar, 1988).

Menurut Daradjat (1978), keyakinan ber. agama menjadi bagian integral dari kepribadian seseorang. Keyakinan itu akan mengawasi segala tindakan, perkataan, bahkan perasaannya. Pada saat seseorang tertarik pada sesuatu yang tampaknya menyenangkan, maka keimårannya akan cepat bertindak menimbang dan meneliti apakah haltersebut boleh atau tidak oleh agamanya.

Agama mempunyai peranan penting dalam pembinaan moral karena nilai-nilai moral yang datang dari agama tetap dan bersifat universal. Apabila dihadapkan pada suatu dilema, seseorang akan menggunakan pertimbangan-pertimbangan berdasarkan nila:rilai moral yang clatang dari agama. Di mana pun orang itu berad a dan pada posisi apapun, dia akan tetap memegang prinsip moral yang telah tertanam dalam hati nuraninya (Daradjat, 1991). Oleh karena itu nilai-nilai agama yang telah diinternalisasi oleh seseorang, diharapkan mampu menuntun semua perifakunya. 
Mangunwijaya (dalam Urbayatun, 1984) membedakan antara istilah religi atau agama dengan istilah religiusitas. Agama menunjuk pada aspek formal yang berkaitan dengan aturan-aturan dan kewajiban-kewajiban, sedangkan religiusitas menunjuk pada aspek yang telah dihayati oleh individu. Hal ini selaras dengan pendapat Dister (1990) yang mengartikan religiusitas sebagai keberagamaan, yang berarti adanya unsur intemalisasi agama itu dalam diri individu.

Di samping dua pendapat di atas, Glock dan Stark (Robertson, 1993) mengatakan bahwa keberagamaan seseorang itu menunjuk pada ketaatan dan komitmen seseorang terhadap agamanya. Berdasarkan pendapatpendapat di atas, dapat dikatakan bahwa keberagamaan seseorang pada dasarnya lebih menunjuk pada proses internalisasi nilai-nilai agama, yang kemudian menyatu dalam diri individu membentuk pola perilaku sehari-hari.

islam senantiasa memastikan agar sikap konsumtif, pemborosan yang disengaja sehingga melebihi batas dan keperluan sehari-hari secara sederhana tidak dijalankan oleh umațnya. Menurut Siddiqi (1991), Islam juga melarang pemborosan dan hidup terlampau mengikuti hawa nafsu duniawi, walaupun kenikmatan yang diperoleh didapat secara sah berdasarkan hukum.

Oleh karena itu, dengan pemahaman keagamaan yang baik seorang ibu rumah tangga yang dihadapkan pada beragamnya tawaran produk yang menggiurkan, tidak akan sembarangan melakukan perilaku membeli. la akan melakukan pertimbanganperlimbangan terlebih dahulu berdasarkan nilai-nilai agama yang sudah terinternalisasi dalam hidupnya. Semakin baik pemahaman dan penghayatannya dalam beragama. ma ka akan semakin baik pula dalam bersikap. membuat perlimbangan, dan memutuskan untuk melakukan pembelian.

\section{HIPOTESIS}

Berdasarkan telah pustaka yang sudah dikemukakan, maka hipotesis yang diajukan datam penelitian ini adalah ada hubungan negatif antara tingkat religiusitas dengan sikap konsumtif pada ibu rumah tangga. Se makin tinggi tingkat religiusitas, semakin rendah sikap konsumtifnya. Sebaliknya, semakin rendah tingkat religusitasnya, maka semakin tinggi sikap konsumtifnya.

\section{MET ODE}

Subjek dalam penelitian ini adalah ibu rumah tangga di Rt 02 RW I Kelurahan Kranji, Kecamatan Purwokerto Timur, Perumahan Purwosari, Kecamatan Baturraden, dan Perumahan Karang Asri, Kecamatan Sokaraja, Kabuparen Banyumas. Ciri-ciri subjek adalah sudah berkeluarga dan beragama Islam.

Data dalam penelitian ini diperoleh dengan menggunakan metode angket. Angket yang digunakan adalah angket sikap konsumilf dan angket retigiusitas. Angket sikap konsumtif disusun berdasarkan faktor-faktor yang mempengaruhi perilaku membeli, yaitu faktor eksternal, faktor internal, dan faktor proses psikologis. Menggunakan model angket skala sikap dengan lima alternatif jawaban, yaitu sangat setuju, setuju, tidak dapat menentukan jawaban, tidak setuju, sangat tidak seluju.

Angket religiusitas disusun berdasarkan lima dimensi religiusitas yang dikemukakan oleh Glock dan Stark (dalam Robertson, 1993). Angket ini disesuaikan pula dengan unsur-unsur yang terdapat dalam ajaran islam, yaitu iman, Islam dan Ikhsan. Angket ini terdiri dari dua bagian. Bagian pertama mengungkap dimensi keyakinan, dimensi praktek agama, dimensi pengalaman, dan dimensi konsekuensi. Angket ini berisi pernyataan-pernyataan dengan tiga alternatif 
jawaban dan sekornya bergerak dari satu (1) sampai tiga (3). Bagian kedua mengungkap dimensi pengetahuan agama yang juga merupakan bagian dari Ikhsan. Angket ini berisi pertanyaan-pertanyaan dengan tiga alternatif jawaban dan sekornya bergerak antara nol (0) dan satu (1).

Analisis data yang digunakan untuk menguji hipotesis dalam penelitian ini adalah korelasi product moment Pearson.

\section{HASIL}

Hasil perhitungan analisis menunjukkan nilai $r_{x y}-0,330$ dengan $p<0,01$. Dengan dernikian dapat disimpulkan bahwa ada hubungan negatif yang sangat signifikan antara tingkat religiusitas dengan sikap konsumtif. Di samping itu nilair ${ }^{2}=0,109$ menunjukkan bahwa sumbangan tingkat religiusitas temadap sikap konsumtif adalah sebesar $10,9 \%$.

Jadi hipotesis yang diajukan, yaitu ada hubungan negatif antara tingkat religiusitas dengan sikap konsumtif, dapat diterima. Semakin tinggi tıngkat religiusitas akan semakin rendah sikap korisumtil. Semakin rendah tingkat religiusitas akan semakin tinggi sikap konsumtif.

\section{DISKUSI}

Bertolak dari hipotesis yang diterima, hasil penelitian menunjukkan bahwa tingkat religivsitas merupakan faktor yang mempengaruhi sikap konsumtif yang aca pada ibu rumah tangga. Selain itu hasil penelitian juga menunjukkan bahwa subjek memp unyai tingkat religiusitas yang relatif tinggi (Bagian I $\mathrm{Me}=88,29 ; \mathrm{Mh}=51$ dan Bagian $\| \mathrm{Me}=$ 10,35 ; Mh $=22,5$ ) dan sikap konsumtit yang relatif rendah ( $M e=67,29$; $M h=85$ ). Mendukung hasil penelitian di atas, Sukardi (1993) mengatakan bahwa kecenderungan masyarakat Indonesia akhir-akhir ini, hampir setiap hari terlihat meningkat pada kegiatankegiatan religi yang tidak lagi hanya menjadi minat orang-orang tua, tetapi juga remaja dandewasa.

lou rumah tangga yang mempunyai tingkat religiusitas tinggi, cenderung untuk mengendalikan sikap konsumtifnya. Hasil penelitian ini mendukung pendapat Hadipranata (1992), yang mengemukakan bahwa agama merupakan salah satu taktor yang mempengaruhi perilaku membeli. Hal ini sesuai juga dengan pendapat Hirschman (dalam Engel dkk., 1990), yang mengatakan bahwa semakin konsumen mengidentifikasikan diri dengan agama yang dianutnya, maka semakin besar kemungkinan pengaruh. nya. Agama meletakkan dasar pengertian dan konsep moral dalam diri seseorang. Konsep moral dari ajaran agama sangat meneniukan sistem kepercayaan, sehingga seringkali ajaran moral dari agama inilah yang menjadi determinan tunggal yang menentukan sikap (Azwar, 1988).

Menu rut Daradjat ( 1978 ) keyakinan ber. agama akan menjadi bagian integral dari kepribadian seseorang. Keyakinan itu akan mengawasi segala tindakan, perkataan, bahkan perasaannya. Pada saat seseorang tertarik pada sesuatu yang tampaknya menyenangkan, maka keimanannya akan cepat bertindak menimbang dan meneliti apakah hal tersebut boleh atau tidak oleh agamanya. Agama mempunyai peranan penting dalam pembinaan moral seseorang karena nilainilai moral yang datang dari agama tetap dan bersifat universal.

Rasionalitas ekonomi beranggapan bahwa konsumen berusaha memaksimumkan 'kepuasan'. Kenyataan bahwa konsumen memiliki sifat yang dipengaruhi oleh ajaran Islam ternyata memberi pengaruh tertentu terhadap motivasi tersebut. Konsumen puas terhadap kehidupan yang mengikuti norma-norma Islam. Kepuasan yang demikian lebih mengacu pada kegunaan. Keada- 
an ini menunjukkan bahwa pemaksimuman kepuasan secara umum tidak dapat dilakukan oleh konsumen yang beragama Islam (Siddiqi, 1991).

lbu rumah tangga yang hidup dalam lingkungan sosial, juga tidak bisa lepas dari masuknya informasi-informasi dan pengalaman-pengalaman, yang ditawarkan olah berbagai media maupun kehidupan bertetangga. Tanpa pedoman hidup yang pasti, seseorang akan mudah terombang-ambing dalam situasi kehidupan yang terus berjatan tanpa kompromi. Sentuhan nilai-nilai agama yang sudah terinternalisasi dalam kehidupan seseorang bisa menjadi dasar dan acuan dalam melakukan pengambilan keputusan berbeianja. Orang berperilaku tidak hanya karena gengsi, emosi atau hal lain yang sifatnya kurang penting. karena keikhlasan dan hati nuraninya sudah terisi dengan nilainilai kebaikan.

Dengan pemahaman keagamaan yang baik, seorang ibu rumah tangga akan mampu melihat, memahami, dan memilah informasi, kebutuhan, dan keinginan yang dihadapi dalam kehidupan sehari-hari, sehingga dalam melakukan perilaku membeli akan berusaha mengambil keputusan yang kritis dan luhur.

\section{PENUTUP}

Berdasarkan hasil penelitian dapat ditarik kesimpulan bahwa tingkat religiusitas mempunyai korelasi yang negatif dengan sikap konsumtif. Hal ini berarti bahwa semakin tinggi tingkat religiusitas yang dimiliki ibu rumah tangga, sikap konsumtifnya semakin rendah. Begitu juga sebaliknya, semakin rendah tingkat religiusitas yang dimiliki ibu rumah tangga, sikap konsumtifnya semakin tinggi.

Berkaitan dengan hasil penelitian ini. penulis mengajukan beberapa saran. yaitu:

\section{Pertama, saran untuk ibu rumah tangga}

Keberhasilan seorang anak sebagai penerus bangsa sangat ditentukan serta diwarnai oleh hasil pendidikan kaum bu terhadap anak-anaknya Karena itu perilaku yang kritis dan luhur dari seorang bu akan menjadi contoh dan teladan bagi anak anak-anaknya. Hasil penelitian yang menunjukkan bahwa muncuinya sikap konsumtif pada ibu rumah tangga dapat dikendalikan oleh tingkat religiusitas atau keberagamaan, seharusnya menjadi masukan bagi para ibu yang merasakan beratnya cobaan dalam mengikuti arus perkembangan barang dan jasa yang terus melaju.

Seorang ibu adalah teladan bagi putraputrinya. Penanaman nilai-nilai baik dan buruk, halal dan haram, serta mengajarkan perilaku membeli yang febih rasional kepada anak-anak adalah saiah satu cara untuk menjaunkan anak dari perilaku konsumtif. Seorang anak secara langsung maupun tidak langsung akan mengidentifikasikan diri dengan orang tuanya. Karena itulah seorang ibu akan menjadi kunci penting bagi kehidupan anak selanjutnya.

Sernua ini bertujuan agar generasi penerus dan kaum wanita Indonesia umumnya. mempunyai pegangan yang kuat dalam menghadapi semakin beragam dan sernakin menawannya barang dan jasa yang ditawarkan oleh proclusen.

Kedua, saran unfuk penelitian selanjutnya

Penelitian ini menunjukkan bahwa masih banyak faktor lain, di luar tingkat religiusitas, yang berpengaruh terhadap linggi rendahnya sikap konsumtif. Bagi peneliti selanjutnya yang berminat terhadap tema ini ada beberapa saran yang perlu diperhatikan. Dalam penelitian ini belum dilihat pengaruh tipe keluarga dan siklus kehidupan keluarga. Setelah menjalani penelitian, masalah keluarga membuka cakrawala pene- 
liti. Tipe keluarga dan siklus kehidupan keluarga juga merupakan masalah yang tidak kalah penting. Seseorang dakam satu keluarga dengan satu anak akan berbeda dengan seseorang di keluarga yang lain dengan jumlah anak banyak. Untuk itu kepada peneliti selanjutnya disarankan untuk mengontrol faktor-faktor di atas.

\section{DAFTAR PUSTAKA}

Azwar, 1988. Sikap Manusia: Tecri dan Pengukurannya(Edisi pertama). Yogyakarta: Penerbit Liberty.

Daradjat, 1978. Peranan Agama dalam Kesehatan Mental. Jakarta: Penerbit Gunung Agung.

-. 1991. Ilmu Jiwa Agama. Jakarta: PT Bulan Bintang.

Dister, N. 1990. Pengalaman dan Motivasi Beragama. Yogyakarta: Penerbit Kanisius.

Engel, F.J., Blacwell, R.D., and Miniard, PW. 1990. Consumer Behavior. Six Edition. New York: The Dryden Press.

Hadipranata, A.F. 1992. Materi Kuliah Psikologi Konsumen. Yogyakarta.

Kottler. P., 1994. Manajemen Pemasaran: Analisis Perencanaan dan Pengen dalian. Jakarta: Penerbit Erlangga.

Nashori. F., 1991. Konsumtivisme Masyarakat Indonesia. Majalah Psikomedia. Edisi 7.
Nashori, F, dan Mindrowo, S 1991. Konsumtivisme dan Konsumerisme: Apa Kata Jaya Suprana? Dalam Majalah PSIKO. MEDIA, Edisi 7.

Robertson, R. 1993. Agama dalam Analisa dan Interpretasi Sosiologis. Rajawali Press. Jakarta: PT. Raja Grafindo Perkasa.

Siddiqi, M.N. 1991. Kagiatan Ekonomi dalam Islam Jakarta: Penerbit Bumi Aksara.

Sukardi, 1.S. 1993. Era Globalisasi Dunia dan Karakteristik Manusia Indonesia yang Tangguh. Jumal Psikologi dan $M a$. syarakat. Jakarta: Penerbit ISPSI dengan PT. Gramedia Widiasarana Indonesia.

Sulistyowati, A. 1989, Perbedaan Keputusan Membeli antara Pria dan Wanita pada Mahasiswa yang Mondok di Yogyakarta. Skripsi(Tidak diterbitkan). Fakutas Psikologi UGM Yogyakarta.

Swastha, B, dan Handoko. T.H. 1987. Mana jemen Pemasaran: Analisa Perilaku Konsumen. Yogyakarta: Penerbit Liberty.

Urbayatun, S. 1984. Hubungan antara Tingkat Religiusitas dan Kecenderungan Neurotik dengan Positive-Negative Affectpada Mahasiswa Muslim Universitas Gadjah Mada, Skripsi (Tidak Diterbitkan). Yogyakarta: Fakultas Psikologi Universitas Gadjah Mada.

Wirawan, S. 1976. Pengantar limu Psikologi. Cetakan I. Jakarta: Penerbit Bulan Bintang. 